\title{
A Rich Morphological Diversity of Biosaline Drying Patterns Is Generated by Different Bacterial Species, Different Salts and Concentrations: Astrobiological Implications
}

\author{
José María Gómez Gómez,,2 Jesús Medina, and Fernando Rull ${ }^{1}$
}

\begin{abstract}
Biosaline formations (BSFs) are complex self-organized biomineral patterns formed by "hibernating" bacteria as the biofilm that contains them dries out. They were initially described in drying biofilms of Escherichia coli cells $+\mathrm{NaCl}$. Due to their intricate 3-D morphology and anhydrobiosis, these biomineralogical structures are of great interest in astrobiology. Here we report experimental data obtained with various alkali halide salts $(\mathrm{NaF}$, $\mathrm{NaCl}, \mathrm{NaBr}, \mathrm{LiCl}, \mathrm{KCl}, \mathrm{CsCl}$ ) on $\mathrm{BSF}$ formation with E. coli and Bacillus subtilis bacteria at two saline concentrations: 9 and $18 \mathrm{mg} / \mathrm{mL}$. Our results indicate that, except for $\mathrm{LiCl}$, which is inactive, all the salts assayed are active during BSF formation and capable of promoting the generation of distinctive drying patterns at each salt concentration. Remarkably, the BSFs produced by these two bacterial species produce characteristic architectural hallmarks as the BSF dries. The potential biogenicity of these biosaline drying patterns is studied, and the astrobiological implications of these findings are discussed. Key Words: Biosaline formationsBiosaline drying patterns-Escherichia coli-Bacillus subtilis-Bacterial biofilms-Morphological biosaline biosignatures-Morphoprinting—Dormant life. Astrobiology 16, 513-524.
\end{abstract}

\section{Introduction}

T HE MAIN GOAL of astrobiology is the search for life in extraterrestrial places (Rothery et al., 2011). Mineralogical biosignatures, produced as part of biomineralization processes (Baeuerlein, 2000), have been intensely studied and are of particular interest in astrobiology as biomarkers in the search for extraterrestrial life-including the search for past or present life on Mars (Banfield et al., 2001).

We recently reported a new kind of the biomineralogical structures called a biosaline formation (BSF) (Gómez Gómez et al., 2014). These self-organized biomineralized bacterial formations with complex 3-D morphologies were first described for a dried droplet of saline solution containing E. coli cells $+(\mathrm{NaCl} 9 \mathrm{mg} / \mathrm{mL})$. These formations have intricate morphologies, ranging from cross-symmetrical structures with complex fractal-like architecture to "fern-leaf" forms (Gómez Gómez et al., 2014). At a structural level, BSFs are layered, with an outer coating of biomineralized material and an underlying layer of tightly interacting bacterial cells, with both biotic (bacteria) and abiotic (salt) components forming part of the same drying pattern. These
BSF structures are formed by whole bacterial cells as they enter a state of dormancy; thus, they are also anhydrobiotic formations. At the formative level, two relevant aspects of the BSF generative process have been described: its kinetic fastness and the fact that both the salt and the bacterial cells are required during self-organization of the biosaline drying patterns (Gómez Gómez et al., 2014). Beyond these initial experimentally discovered features, the molecular mechanisms underlying BSF formation remain largely unknown.

The objective of this investigation was to learn more about the influence of the salt and the bacteria on the genesis of a BSF, addressing two key questions: firstly, whether salts other than $\mathrm{NaCl}$ - but with a similar cubic crystal—can also promote BSF formation; secondly, whether these formations are generated exclusively by $E$. coli or whether it is a more generalized phenomenon that can be observed with other bacterial species.

\section{Results}

To gain an insight into the role that different ionic salts and different bacteria play on the biosaline drying process,

\footnotetext{
${ }^{1}$ Laboratory of BioMineralogy and Astrobiological Research (LBMARS), Unidad Asociada UVA-CSIC, Edificio INDITI, Boecillo, Valladolid, Spain.

${ }^{2}$ OAS-BioAstronomy Group, Observatorio Astronómico de Segurilla (OAS), Segurilla, Toledo, Spain.
} 
we carried out a number of BSF formative experiments (as described previously in Gómez Gómez et al., 2014) using the E. coli K-12 MG1655 and Bacillus subtilis BD170 strains (Hanlin et al., 1985) as biological material. We used various alkali-halide salts $(\mathrm{NaF}, \mathrm{NaBr}, \mathrm{LiCl}, \mathrm{KCl}$, and $\mathrm{CsCl}$ ), all of which have a different monovalent ion composition from $\mathrm{NaCl}$ but which all form cubic crystals. Thus, $\mathrm{NaF}, \mathrm{NaBr}, \mathrm{LiCl}$, and $\mathrm{KCl}$ form the same type of crystals as $\mathrm{NaCl}$, but they differ in their corresponding lattice constants, while $\mathrm{CsCl}$ forms crystals in a simple cubic lattice type (Sirdeshmukh et al., 2001). In addition, by employing two different concentrations of each salt $(9$ and $18 \mathrm{mg} / \mathrm{mL}$ ), we looked at the effect of saline concentration on BSF formation. Optical (Fig. 1, Figs. 4 and 5) and scanning electronic microscope (SEM) (Figs. 2 and 3) images were taken as described in Gómez Gómez et al. (2014) and show typical biosaline drying patterns observed in the dried sessile droplets prepared with these salts. The same number of bacterial cells in the sessile evaporating droplets (approximately $2.5 \times 10^{9}$ ) was used in all experiments.

Several important results can be summarized from the figures:

(i) With E. coli, lithium chloride ( $\mathrm{LiCl})$ does not promote BSF formation at $9 \mathrm{mg} / \mathrm{mL}$ (compare Fig. $1 \mathrm{~A}$ to $1 \mathrm{~B}$ and Fig. $2 \mathrm{~A}$ to $2 \mathrm{~B}-2 \mathrm{C}$ ). Only the typical cubic $\mathrm{LiCl}$ crystals could be clearly observed in the dried droplets of $E$. coli+ ( $\mathrm{LiCl} 9 \mathrm{mg} / \mathrm{mL}$ ) (Fig. 1B). In the dried droplets of E. colit $(\mathrm{LiCl} 18 \mathrm{mg} / \mathrm{mL})$, drying structures in the form of a "Greek cross" (Fig. 1C) were observed; however, at higher magnification using the SEM, these were seen to be formed by bulky structures of $\mathrm{LiCl}$ (Fig. 3A-3B). Likewise, in dried droplets of $B$. subtilis $+(\mathrm{LiCl} 9 \mathrm{mg} / \mathrm{mL})$, the $\mathrm{LiCl}$ was also completely inactive in terms of generating BSFs (compare Fig. 4A to 4B). Thus, both bacterial species are seen to have a similar BSF behavior in evaporating sessile droplets containing $\mathrm{LiCl}$.

Interestingly, inside the control samples prepared only with $\mathrm{LiCl}$, the typical cubic crystals observed in the E. coli+ ( $\mathrm{LiCl} 9 \mathrm{mg} / \mathrm{mL}$ ) droplets were not formed, but only aqueous droplets (Fig. 1N). This behavior is probably explained by the elevated hygroscopicity of the $\mathrm{Li}^{+}$cation (Wright, 2007). Moreover, this result suggests that the formation of cubic crystals in drying droplets of $E$. coli $+(\mathrm{LiCl} 9 \mathrm{mg} / \mathrm{mL})$ could be promoted by the bacteria.

(ii) The other halide salts assayed ( $\mathrm{NaF}, \mathrm{NaBr}, \mathrm{KCl}$, and $\mathrm{CsCl}$ ) did promote BSFs in droplets containing either $E$. coli or B. subtilis bacterial cells, at both 9 and $18 \mathrm{mg} / \mathrm{mL}$ concentrations. Thus, in the dried E. coli $+(\mathrm{NaF} 9 \mathrm{mg} / \mathrm{mL})$ droplets, $\mathrm{NaF}$ promoted the generation of characteristic round micrometric BSFs (Figs. 1D and 2D-2E), whereas at $18 \mathrm{mg} / \mathrm{mL}$ the BSFs generated had a characteristic "deformed rhomboid" geometry (compare Fig. 1D to 1E and Fig. 2D-2E to Fig. 3C-3E). On the other hand, in the dried B. subtilis $+(\mathrm{NaF} 9 \mathrm{mg} / \mathrm{mL})$ droplets, the $\mathrm{NaF}$ promoted the formation of small round patterns (Fig. 4D) similar to those observed in the dried droplet of this salt with $E$. coli (compare Fig. 1D to Fig. 4D-4E). At $18 \mathrm{mg} / \mathrm{mL}$, the interaction between $B$. subtilis $+(\mathrm{NaF} 18 \mathrm{mg} / \mathrm{mL})$ generated "dinosaur footprint" patterns (Fig. 4C).

$\mathrm{NaBr}$ generated a characteristic "elk-horn-like" pattern (Figs. $1 \mathrm{~F}-1 \mathrm{G}$ and $2 \mathrm{~F}-2 \mathrm{~J}$ ) in interaction with $E$. coli at $9 \mathrm{mg} / \mathrm{mL}$, but in dried biofilms of $E$. coli $+(\mathrm{NaBr} 18 \mathrm{mg} / \mathrm{mL})$, the drying patterns exhibited a branching "diffusion-limited aggregation (DLA)-like" structure (Fig. 1H-1I)—so called because structures similar to these can be produced by a DLA process (Ball, 1999). In contrast, the dried droplets prepared with B. subtilis cells $+(\mathrm{NaBr} 9 \mathrm{mg} / \mathrm{mL})$ contained thin needles or "spicule" formations (Fig. 4F) that were very different from the DLA-like drying patterns observed for the dried droplets of $E$. coli cells $+(\mathrm{NaBr} 9 \mathrm{mg} / \mathrm{mL})$ (Figs. 1F-1G and 2F).

For $\mathrm{KCl}$, the dried droplets prepared with $E$. coli $+(\mathrm{KCl}$ $9 \mathrm{mg} / \mathrm{mL}$ ) produced fractal-like "Christmas-tree" patterns (Figs. 1J and 2K-2L). No such drying patterns were observed by Gómez Gómez et al. (2014) for $E$. coli $+(\mathrm{NaCl}$ $9 \mathrm{mg} / \mathrm{mL}$ ) (Fig. 5A). At the higher concentration of $\mathrm{KCl}$ $18 \mathrm{mg} / \mathrm{mL}$, the biosaline $E$. coli drying pattern was a thinner structure, more like the DLA-like dendritic structure (compare Fig. $1 \mathrm{~J}$ to $1 \mathrm{~K}$ and Fig. $2 \mathrm{~K}-2 \mathrm{~L}$ to Fig. $3 \mathrm{~F}-3 \mathrm{H})$. The B. subtilis $+(\mathrm{KCl} 9 \mathrm{mg} / \mathrm{mL})$ drying patterns (Fig. $4 \mathrm{G}-4 \mathrm{H})$ superficially resembled the $E$. coli $+(\mathrm{KCl} 9 \mathrm{mg} / \mathrm{mL})$ ones (compare Fig. $4 \mathrm{G}-4 \mathrm{H}$ to Fig. $1 \mathrm{~J}$ ); in addition, there is some similarity between the B. subtilis $+(\mathrm{KCl} 18 \mathrm{mg} / \mathrm{mL})$ and $E$. coli $+(\mathrm{KCl} 18 \mathrm{mg} / \mathrm{mL})$ drying patterns (compare Fig. 4I-4J to Fig. 1K), but in their overall morphological architecture there are clear differences in the morphology of the biosaline patterns for these two bacterial species in interaction with $\mathrm{KCl}$ salt at 9 and at $18 \mathrm{mg} / \mathrm{mL}$.

For $\mathrm{CsCl}$, dried droplets containing $E$. coli cells $+(\mathrm{CsCl}$ $9 \mathrm{mg} / \mathrm{mL}$ ) revealed characteristic "densely branched", patterns (Ball, 1999), with branches emerging from a central nucleus (Figs. $1 \mathrm{M}$ and $2 \mathrm{M}-2 \mathrm{~N}$ ). In dried droplets of E. coli $+(\mathrm{CsCl} 18 \mathrm{mg} / \mathrm{mL})$, a dramatically different morphology is generated, with only the typical "star" patterns, including "cloverleaf"' structures, being observed at this concentration (Figs. $1 \mathrm{~L}$ and $3 \mathrm{~L}-3 \mathrm{~N}$ ). In interaction with B. subtilis, the $\mathrm{CsCl}$ generated very different patterns (Fig. $4 \mathrm{~K}-4 \mathrm{O}$ ) to E. coli (Figs. $1 \mathrm{~L}-1 \mathrm{M}$ and $2 \mathrm{M}-2 \mathrm{~N}$ ). For example, in dried biofilms of $B$. subtilis $+(\mathrm{CsCl} 18 \mathrm{mg} / \mathrm{mL})$, we observed a characteristic drying pattern with a strong cross-symmetrical structure exhibiting "four crossed-arms" structures that generate branched dendritic structures (Fig. 4M).

(iii) The biosaline drying pattern of $E$. coli $+(\mathrm{NaCl}$ $18 \mathrm{mg} / \mathrm{mL}$ ) was very different from that observed for $9 \mathrm{mg} / \mathrm{mL}$ (Gómez Gómez et al., 2014). At the higher concentration, a denser "branching pattern" was typically observed (Fig. 5B-5C), rather than the cross-symmetrical pattern with a cubic crystal core with fractal-like structures observed at $9 \mathrm{mg} / \mathrm{mL}$ (Fig. 5A). Intriguingly, these "branching patterns" are morphologically similar to the "densely branched" patterns observed in $E$. coli $+(\mathrm{CsCl} 9 \mathrm{mg} / \mathrm{mL})$ biofilms (compare Fig. 1M to Fig. 5B-5C). It is remarkable that the dried B. subtilis $+(\mathrm{NaCl} 9 \mathrm{mg} / \mathrm{mL})$ droplets showing the typical cross-symmetrical patterns that develop fractallike structures have similar morphologies to the fractallike drying pattern of E. coli [compare Fig. 5A (E. coli) to 5D (B. subtilis)]. The fern-leaf pattern is not observed with $B$. subtilis BSFs (Fig. 5E-5F). However, at the higher salt concentration, the B. subtilis $+(\mathrm{NaCl} 18 \mathrm{mg} / \mathrm{mL})$ drying patterns had a cross-symmetrical architecture, but the fractal-like structures were not completely developed (Fig. 5G-5H), in contrast to the branching patterns of the 


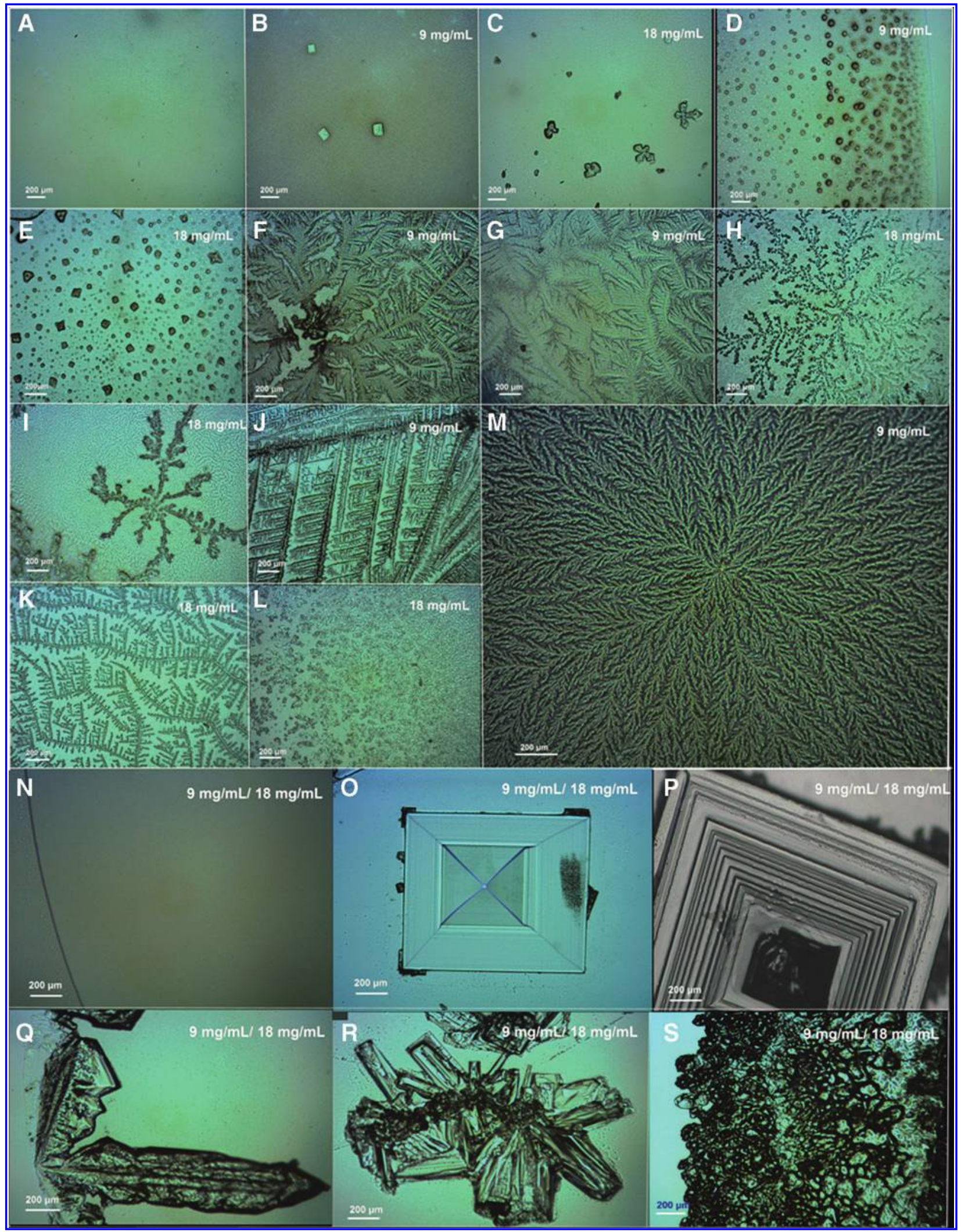

FIG. 1. Morphological diversity of the BSF patterns of E. coli with different halide salts and concentrations. (A-M) Optical microscope images of typical biosaline drying patterns for Escherichia coli K-12 MG1655 strain inside dried sessile saline droplets prepared with different halide salts at 9 and $18 \mathrm{mg} / \mathrm{mL}$, as indicated in each image. (A) Control: bacterial cells in Milli-Q water; (B, C) LiCl; (D, E) NaF; (F-I) NaBr; (J, K) KCl; (L, M) CsCl. (N-S) Typical drying patterns observed in control droplets prepared with salt solutions only: (N) $\mathrm{LiCl} ;(\mathbf{O}) \mathrm{NaCl} ;(\mathbf{P}) \mathrm{NaF} ;(\mathbf{Q}) \mathrm{NaBr} ;(\mathbf{R}) \mathrm{KCl} ;(\mathbf{S}) \mathrm{CsCl}$. 


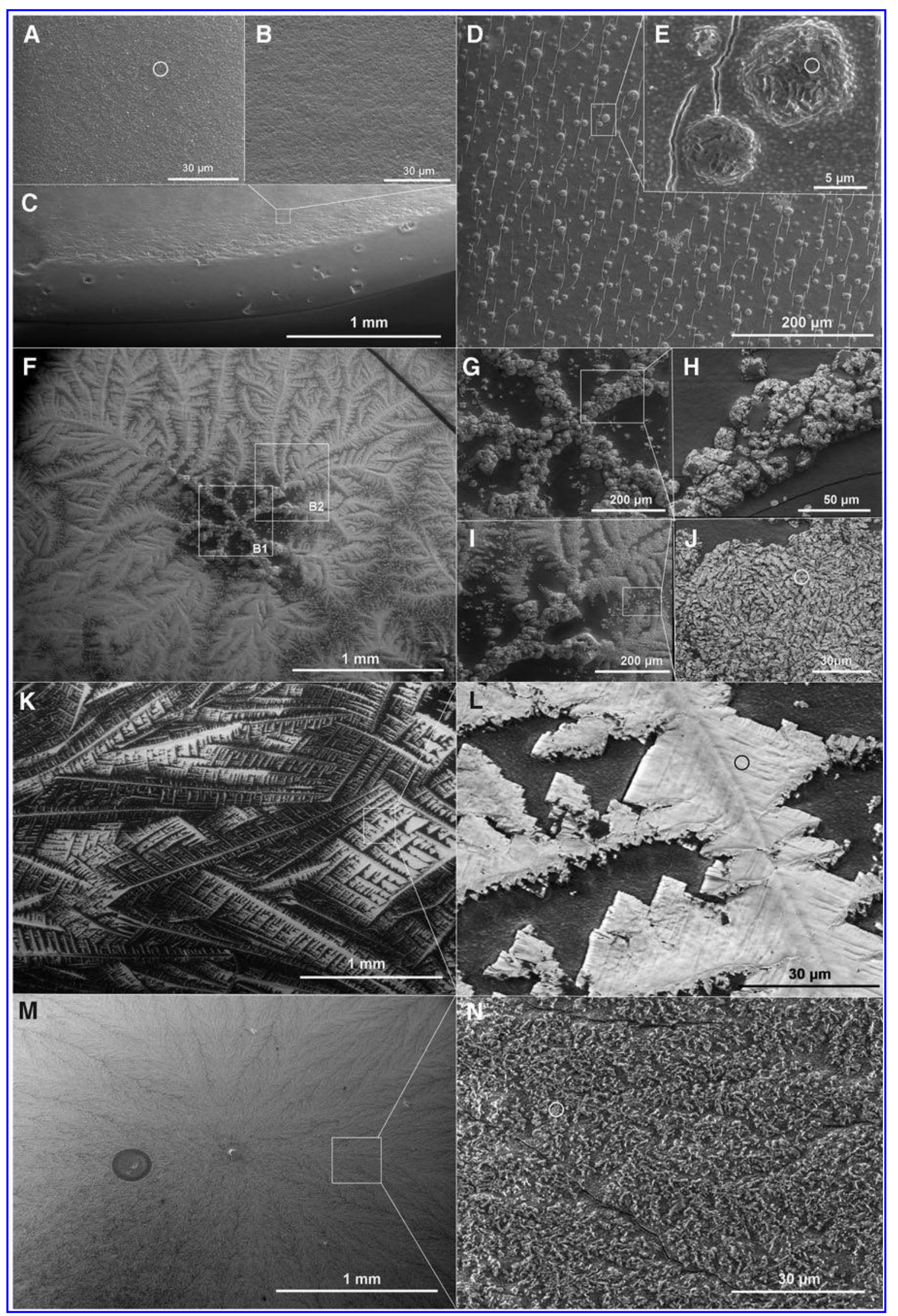

FIG. 2. SEM images of typical E. coli K-12 MG1655 BSFs at $9 \mathrm{mg} / \mathrm{mL}$. (A) Control: bacterial cells in Milli-Q water; (B, C) $\mathrm{LiCl}$; (D, E) NaF; (F-J) NaBr, (G) enlargement of box B1 in (F), (I) enlargement of box B2 in (F); (K, L) KCl; (M, N) $\mathrm{CsCl}$. 


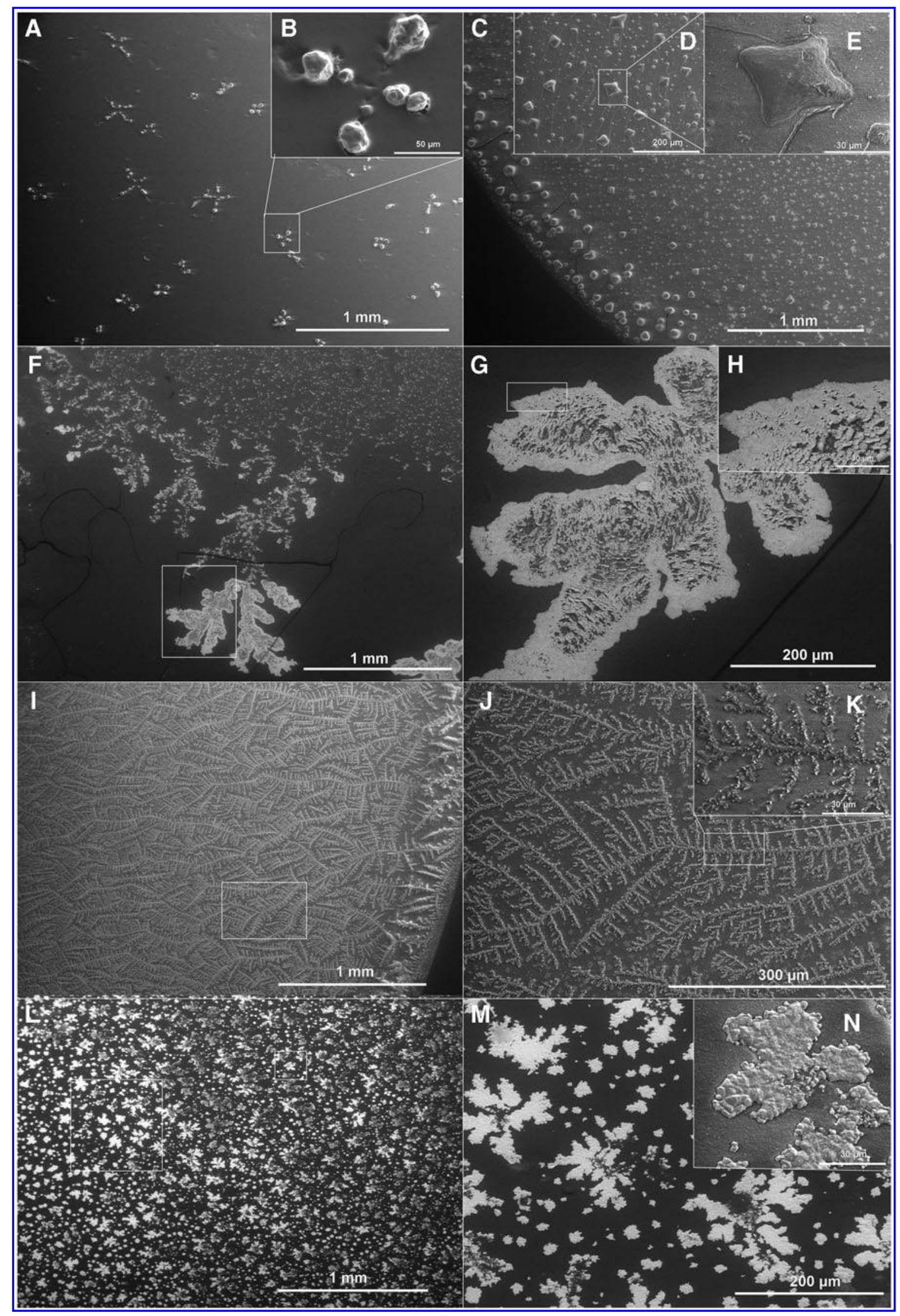

FIG. 3. SEM images of $E$. coli $\mathrm{K}-12 \mathrm{MG} 1655$ drying patterns at $18 \mathrm{mg} / \mathrm{mL}$. (A, B) $\mathrm{LiCl}$; (C-E) $\mathrm{NaF} ;(\mathbf{F}-\mathbf{H}) \mathrm{NaBr},(\mathrm{G})$ enlargement of box in (F), (H) enlargement of box in $(\mathrm{G}) ;(\mathbf{I}-\mathbf{K}) \mathrm{KCl},(\mathrm{J})$ enlargement of box in (I); (L-N) CsCl, (M) enlargement of the large box in $(\mathrm{L}),(\mathrm{N})$ close-up view of the small box in $(\mathrm{L})$. 


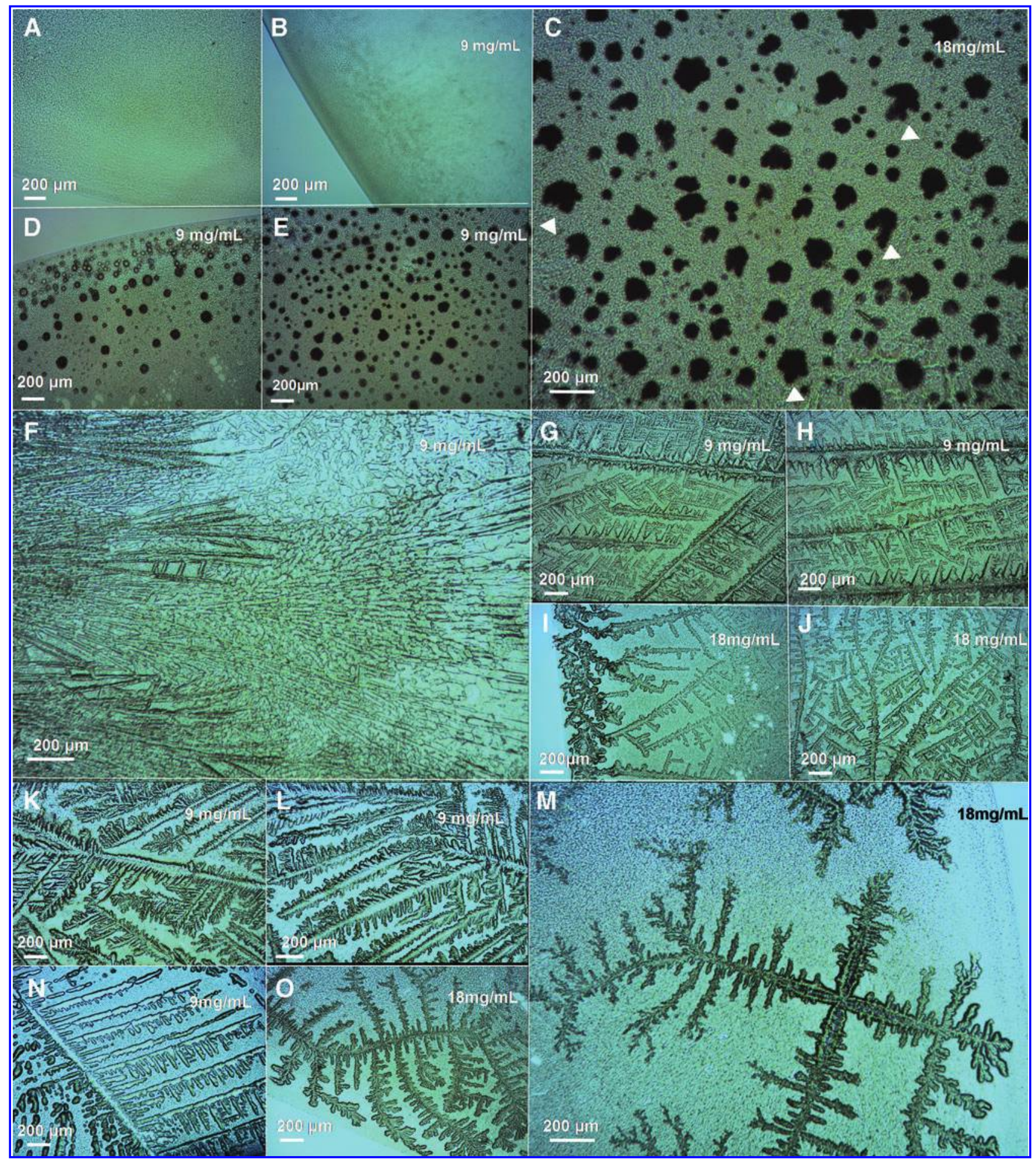

FIG. 4. Morphological diversity of the BSF patterns of B. subtilis with different halide salts and concentrations. Optical microscope images of typical B. subtilis BD170 biosaline drying patterns observed inside dried sessile saline droplets prepared with different halide salts at 9 and $18 \mathrm{mg} / \mathrm{mL}$, as indicated in the images. (A) Control: cells in Milli-Q water; (B) $\mathrm{LiCl}$; (C-E) $\mathrm{NaF}$, in (C) the arrowheads indicate typical "dinosaur footprint" patterns; $(\mathbf{F}) \mathrm{NaBr}$; $(\mathbf{G}-\mathbf{J}) \mathrm{KCl}$; (K-O) $\mathrm{CsCl}$.

E. $\operatorname{coli}+(\mathrm{NaCl} 18 \mathrm{mg} / \mathrm{mL})$ BSF. Furthermore, while "proteoglycan aggregate-like" patterns (Berg et al., 2007) were observed inside the $B$ subtilis dried droplets (Fig. 5I), these kinds of patterns were not observed in the $E$. coli $+(\mathrm{NaCl}$ $9 \mathrm{mg} / \mathrm{mL}) \mathrm{BSF}$. (iv) Importantly, none of the various biosaline drying patterns whose morphologies are described above were observed in the control droplets containing salt-only solutions (Fig. 1N-1S). This confirms that both the components-bacteria and salt_-are required for BSF formation. 


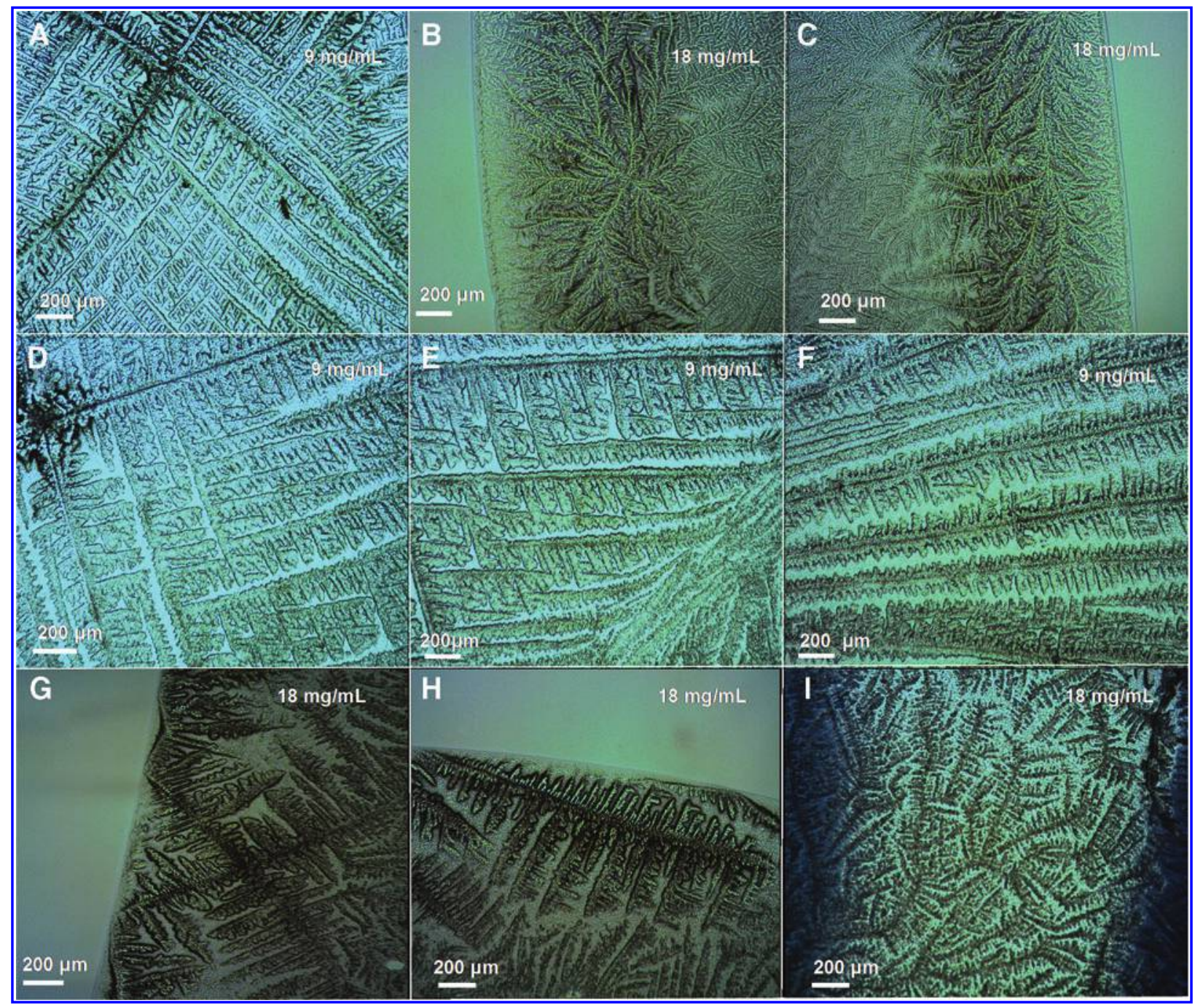

FIG. 5. BSF patterns with $\mathrm{NaCl}$. Optical microscope images of typical BSFs generated by E. coli K-12 MG1655 strain and B. subtilis BD170 strain at $9 \mathrm{mg} / \mathrm{mL} \mathrm{NaCl}$ and $18 \mathrm{mg} / \mathrm{mL} \mathrm{NaCl}$ in dried saline droplets, as is indicated in the images. (A-C) E. coli; (D-I) B. subtilis.

Figure 6 shows the energy dispersive X-ray (EDX) analysis of the filmlike thin layer that constitutes the dried biomineralogical material formed by the salt in the BSF ( $\mathrm{NaF}, \mathrm{NaBr}, \mathrm{CsCl}, \mathrm{KCl}$, respectively). This demonstrates that the salts are conjugated to and intermingle with organic materials to form the characteristic outer biomineralized layer. In this figure, the spectrum of $\mathrm{NaCl}$ has also been included as a reference (see also Gómez Gómez et al., 2014).

Taken together, these results reveal three important findings: firstly, different drying pattern morphologies were generated at each salt concentration $(\mathrm{NaF}, \mathrm{NaBr}, \mathrm{CsCl}$, and $\mathrm{KCl}$ ); secondly, a dramatic difference in the morphology of biosaline drying patterns was observed between the 9 and $18 \mathrm{mg} / \mathrm{mL}$ concentrations; thirdly, B. subtilis produced very different drying patterns from $E$. coli in the biosaline droplets with $\mathrm{NaBr}, \mathrm{KCl}$, and $\mathrm{CsCl}$ at both concentrations (compare Fig. 1 to Fig. 4) but exhibited similarities and differences with $\mathrm{NaF}$ (compare Fig. 1D to Fig. 4D and Fig. 1E to Fig. 4C) and $\mathrm{NaCl}$ (compare Fig. 5A-5C to 5D-5I).
Importantly, we tested the idea that these biosaline drying patterns could represent morphological biosignatures with a reliable biogenicity. Proposing that a phenomenon is a "biosignature" means proposing that targets fall into one of three classes: abiotic/mineral, organic or biotic, and that the putative "biosignature" observation is the result of a "biotic" phenomenon, not an abiotic or organic one. Hence, we included two additional controls in our experiments: montmorilloniteNa (MontNa) (Early et al., 1953), which is very soft phyllosilicate clay (the grain size used in this study was of $<25 \mu \mathrm{m}$ ) as the abiotic (mineral) control, and humic material (HM, EMUFLOR universal substrate, $80 \%$ organic matter) (grain size of $<40 \mu \mathrm{m}$ ) as the organic control.

Figure 7 shows the saline drying patterns (SDPs) observed in dried droplets containing different MontNa + salts concentrations. As with the bacteria, the $\mathrm{NaLi}$ does not promote SDP formation with this clay (Fig. 7C-7D). On the other hand, while $\mathrm{NaBr}$ (Fig. 7E-7F) and $\mathrm{CsCl}$ (Fig. 7G$7 \mathrm{H})$ were also inactive in terms of promoting formation of SDPs (contrary to the result obtained with bacteria, Figs. 1 and 4), the $\mathrm{NaF}, \mathrm{NaCl}$, and $\mathrm{KCl}$ were active in generating 


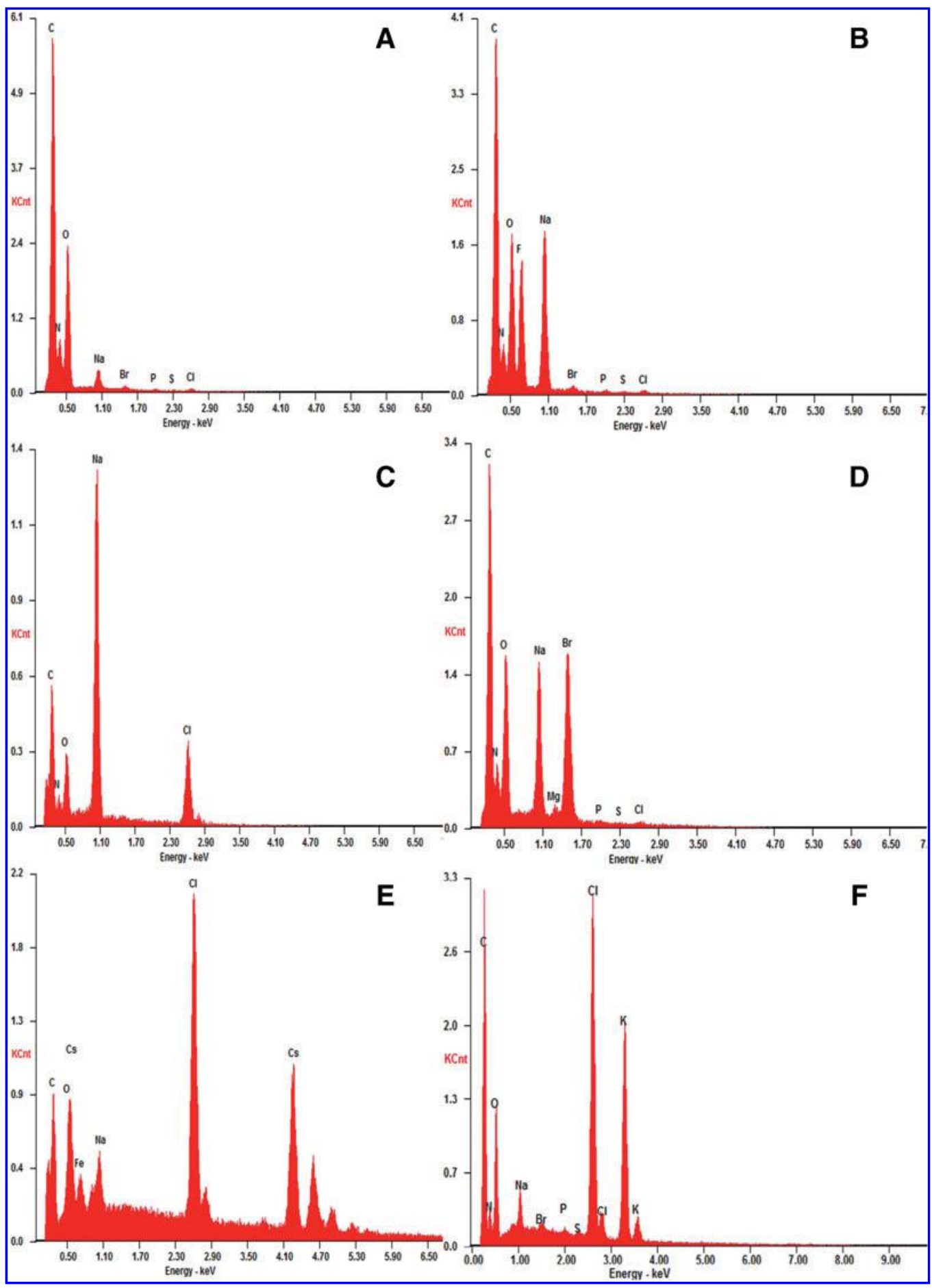

FIG. 6. Typical EDX spectra obtained in the open circles in Fig. 2 images (A), (E), (J), (L), and (N). (A) Control: E. coli K-12 MG1655 strain cells in Milli-Q water; (B) NaF; (C) NaCl; (D) NaBr; (E) CsCl; (F) KCl. The EDX spectrum of $\mathrm{NaCl}$ has been included as a reference. These spectra were obtained as was previously reported in Gómez Gómez et al. (2014).

SDP formation. Notably, MontNa $+\mathrm{NaF}$ drying patterns showed rounded forms (Fig. 7I-7K), formations with "deformed rhomboid" geometry (Fig. 7L), and "dinosaur footprint" patterns exhibiting morphological similarity with those observed in bacteria + NaF BSFs (compare Fig. 7I-7L to Fig. 1D and Fig. 2D-2E). This indicates that the morphology of these SDPs can also be produced by abiotic processes. In dried droplets of MontNa $\mathrm{KCl}$, DLA-like dendritic patterns were observed (Fig. 7M-7N) and formations with a cross-shaped geometry (Fig. 7O-7P). The Mont $\mathrm{Na}+\mathrm{NaCl}$ drying patterns have a clearly different morphology than the biosaline drying patterns observed in dried droplets of bacteria $+\mathrm{NaCl}$ (compare Fig. 7Q-7T to Fig. 5A-5C). 


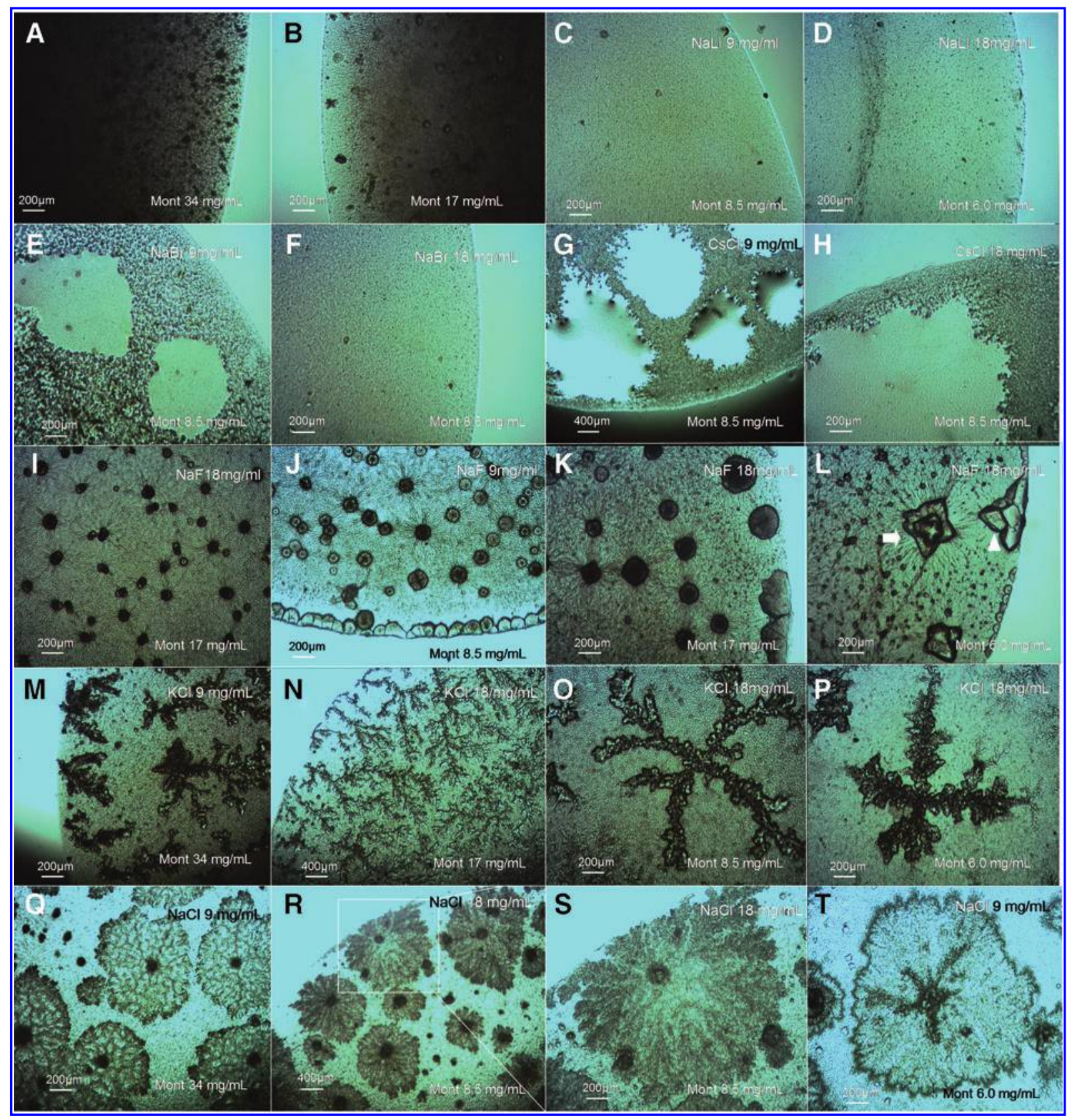

FIG. 7. (A-T) Optical microscopic images of typical drying patterns of MontNa observed inside dried droplets at different concentrations of MontNa and halide salts, as indicated in the figure. The dried droplet controls at MontNa $8.5 \mathrm{mg} / \mathrm{mL}$ and MontNa $6 \mathrm{mg} / \mathrm{mL}$ concentrations have a similar appearance to images (C) and (D). In (L), the arrowhead indicates a "dinosaur footprint" pattern and the arrow a "deformed rhomboid" formation.

Figure 8 shows the SDP formation inside droplets containing $\mathrm{HM}+$ salts at different concentrations of salts and HM. In a similar way to bacteria and MontNa, NaLi was inactive in terms of generating SDPs (data not shown). Interestingly, in dried droplets containing $\mathrm{NaCl}+\mathrm{HM}$ (Fig. 8A-8D) we observed SDP formations that, in some cases, showed certain similarities with the $\mathrm{NaCl}$ bacterial biosaline drying patterns (compare Fig. $8 \mathrm{~A}-8 \mathrm{D}$ to Fig. 5A) - for example, a $\mathrm{NaCl}$ seed crystal with fractallike structures emanating from its corners (Fig. 8A) - but without the complexity of the $\mathrm{NaCl}$ bacterial BSFs
(Fig. 5A-5C, Gómez Gómez et al., 2014). That is, the bacterial $\mathrm{NaCl}$ drying patterns exhibited greater subtlety in their morphological organization. $\mathrm{NaBr}$ and $\mathrm{CsCl}$ were also inactive in the formation of saline humic drying patterns (data not shown). Different formations were observed at the edge of droplets of $\mathrm{HM}+\mathrm{NaF}$ material: rounded (Fig. 8E-8F) and veil-like forms (Fig. 8G-8H). In dried droplets of $\mathrm{HM}+\mathrm{KCl}$, we observed SDPs showing a characteristic cross-shaped geometry (Fig. 8I-8L), which was not observed in BSFs of bacteria $+\mathrm{KCl}$ (Figs. $1 \mathrm{~J}-1 \mathrm{~K}$, $2 \mathrm{~K}-2 \mathrm{~L}$, and $4 \mathrm{G}-4 \mathrm{~J})$. 


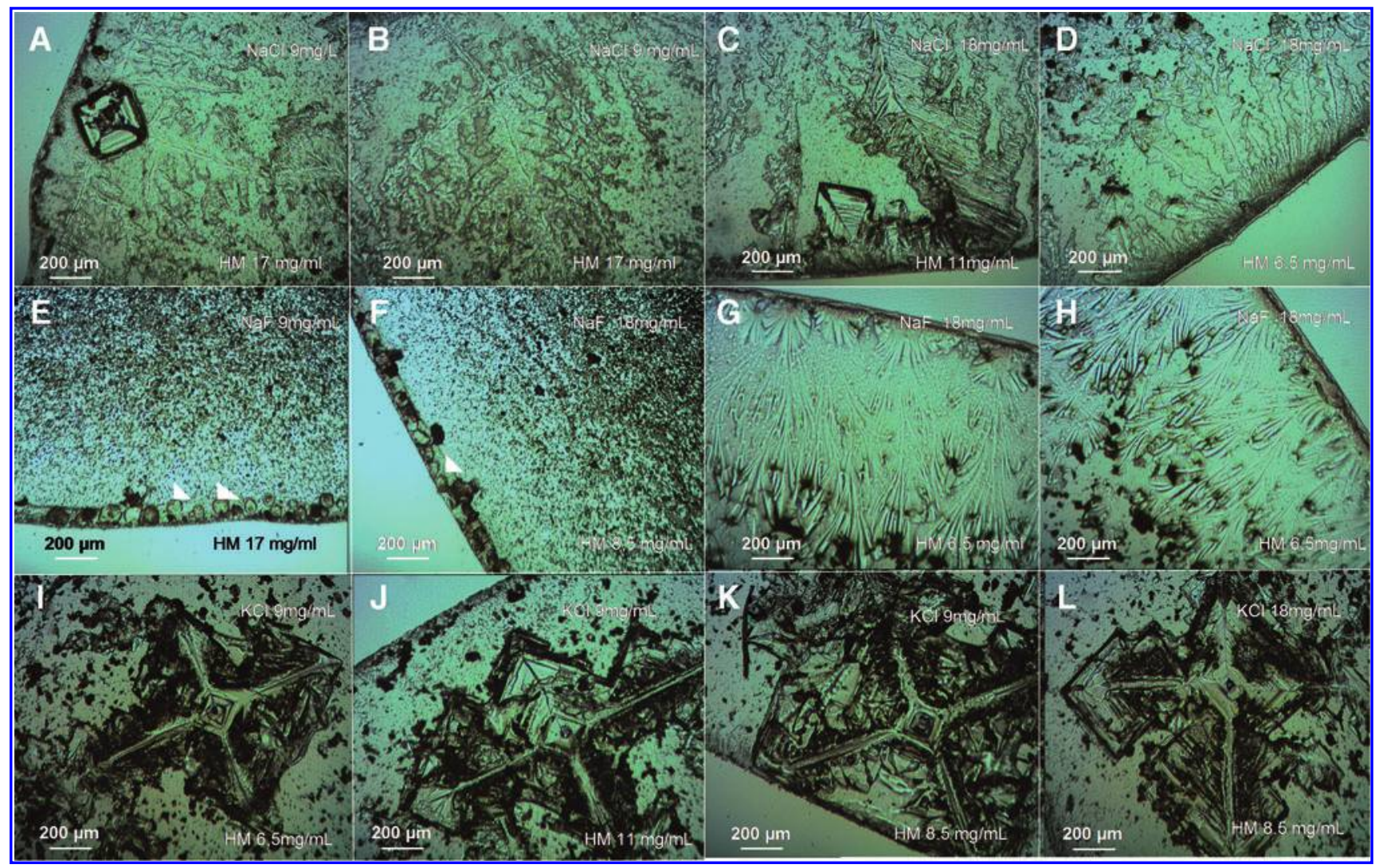

FIG. 8. (A-L) Optical microscopic images of SDPs inside dried droplets containing HM + salts. The concentrations of the salts and HM are indicated in the figure. The drying patterns in these images were not observed inside control droplets (data not shown). The arrowheads indicate rounded formations.

\section{Discussion}

This study has extended the knowledge about the salts and bacterial species that can be active in the generation of BSFs. We found that the two bacterial species (E. coli and B. subtilis) producing drying BSFs have different morphological fingerprinting ("morphoprinting"), probably implying that each species modulates the nucleation and crystal growth of each salt in a specific manner, that is, differentially. This would create a characteristic hallmark or biosaline "bacterioform" (a term coined by Reith et al., 2006) in the biosaline drying patterns, which could be specifically ascribed to a particular bacterial species.

How could this modulation be carried out by the bacteria? In a previous article (Gómez Gómez et al., 2014), we speculated about the possibility that the assemblage of $\mathrm{NaCl}$ and bacterial cells in the various morphs of BSFs could be controlled by the bacterial cells, probably by means of organic polymers, for example, the protean component(s) or other kinds of extrapolymeric substances (EPS, such as exopolysaccharides, adhesive proteins, or extracellular DNA) secreted by the bacteria into the surrounding medium over the period of BSF formation in the evaporating droplet (Gómez Gómez et al., 2014). This extracellular EPS matrix, which is typically self-produced during bacterial biofilm formation (Beloin et al., 2008; López et al., 2010), could be acting as a template or scaffold, which promotes the for- mation and organization of the $\mathrm{NaCl}$ deposition during $\mathrm{BSF}$ formation and which eventually incorporates the entire cell into the self-assemblage, so generating the drying $E$. coli+ $\mathrm{NaCl}$ structures (Gómez Gómez et al., 2014).

In this hypothetical formation scenario, the bacterial cells and salts might be separated by a thin film of newly excreted EPS extracellular matrix. However, the last-mentioned possibility was not addressed in our experiment, so it is not yet possible to ascertain if the difference between the E. coli + salt and B. subtilis + salt drying patterns could be the result of direct interaction between the halide ions and charged components in the cell walls of the bacteria (Silhavy et al., 2010). Such charged components of bacterial cell walls include phosphate groups attached to the lipopolysaccharide of the outer membrane (OM) in E. coli (Gram-negative bacteria) or the phosphate groups of teichoic acids present in the envelope of B. subtilis (Grampositive bacteria) cells, which lack the OM layer (Silhavy et al., 2010). Thus, we cannot yet ascertain whether the bacterial cell surface itself is involved in BSF formation or whether the OM per se could be the principal BSF differentiator between the two bacterial species. This is an important issue to be addressed in our future investigations.

Morphological signatures are a controversial kind of biosignature [a typical case was the claim of the existence of putative "bacterial-like" forms observed on the martian meteorite ALH84001 (Golden et al., 2001)] because it is 
difficult to certify complete biogenicity to biomorphological signatures (i.e., to certify that there are no abiotic mimics so that the individual patterns can be ascribed as bona fide indicators of the evidence of life; Cady et al., 2003). In taking account of these precedents, we can ask: what are the astrobiological implications of our novel findings of bacterial BSFs presented in this article?

The results obtained in the experiments of the control containing MontNa and $\mathrm{HM}+$ salts at various concentrations (Figs. 7 and 8) have demonstrated that, in some cases, the bacterial biosaline drying patterns do have imitations in the abiotic/organic world (e.g., rounded formations and DLA-like patterns). Therefore, these kinds of patterns cannot be classified as reliable morphological biosignatures. In contrast, we identified biosaline drying patterns in dried droplets containing bacteria + salts $(\mathrm{NaBr} / \mathrm{NaCl} / \mathrm{KCl} / \mathrm{CsCl})$ that do not have imitations in the mineral (MontNa)/organic (HM) domains assayed in this study (compare Figs. 7 and 8 to Figs. 1-5). Therefore, these last-mentioned patterns can be considered - in principle - as potential biosaline morphological biosignatures. To our knowledge, for instance, neither the B. subtilis $+(\mathrm{CsCl} 18 \mathrm{mg} / \mathrm{mL})$ drying pattern with the four long-armed cross-symmetrical structure (Fig. 4M) nor the "elk-horn-like" patterns (Figs. 1F and 2F) have been described before either in bacterial biofilms or in the inorganic abiotic world. Nonetheless, patterns with crosssymmetrical organization were observed in dried droplets of MontNa $+\mathrm{KCl}$ (Fig. 7O-7P) or $\mathrm{HM}+\mathrm{KCl}$ (Fig. 8I-8L), but these morphological organizations have a different overall appearance. The possibility that interaction of salts used in this study with other minerals (e.g., different clays with other grain sizes) or organic materials (e.g., specific kinds of proteins or EPS material) could generate imitations of these patterns cannot be completely excluded.

In any case, we consider that morphology of BSFs should be considered as interesting potential morphological biomarkers that should be included in the search for extraterrestrial life.

With the goal of producing a significant database of mineral, organic, and biotic SDPs, in future investigations we will continue exploring the morphospace of BSFs generated by other bacterial species and mineral salts, as well as further control experiments (i.e., different kinds of clay and organic materials). We would also aim to generate a sufficient number of samples in each class and produce statistics on the likelihood that an observed morphology belongs to a particular class. A further aim would be to develop an algorithm for classifying drying patterns that is capable of generating a probabilistic prediction of the appropriate organic/abiotic/biological assignment. To create this algorithm, we would need to consider the drying patterns of several large data sets; in this respect, the images of drying patterns presented in this paper indicate the different kinds of properties that would need to be incorporated into the algorithm, for example, fractality, symmetry, intricateness, and general organization.

\section{Conclusions}

In this investigation we have presented experimental evidence that another bacterial species-B. subtilis - is able to generate biosaline drying formations, so expanding this bacterial BSF self-formative phenomenon beyond $E$. coli bacteria. We show that the morphological signatures of BSFs created by $E$. coli and B. subtilis are very diverse. They are an extraordinary example of self-organized biomineralogical signatures with a potentially reliable biogenicity. This is a relevant astrobiological property in the search for dormant extraterrestrial life. Our findings indicate that dormant life could be concealed beneath salt + bacteria coatings with various morphologies in places where salts have been detected-places as different as Mars (Osterloo et al., 2008) and the icy moons of Jupiter (Europa) (McCord et al., 1998) or Saturn (Enceladus) (Postberg et al., 2011). In our previous study (Gómez Gómez et al., 2014), we suggested that biosaline drying patterns might serve as biomarkers that are detectable by imaging systems during planetary exploration. The novel images presented here reinforce this idea.

\section{Acknowledgments}

The authors express their gratitude to J.C. Alonso from the Centro Nacional de Biotecnología (CNB) for kindly providing the Bacillus subtilis BD170 strain and to M.A. Moreno from the Unidad de Microscopia Avanzada de la Fundación Parque Científico Universidad de Valladolid for technical support. We also thank an anonymous reviewer for constructive comments, which allowed us to improve our manuscript. The research was supported by the Spanish Ministerio de Economía y Competividad (MINECO) (Grant $\mathrm{N}^{\circ}$ ESP2013-48427-C3-2-R).

\section{Disclosure Statement for All Authors}

The authors declare that they have no competing interests.

\section{References}

Baeuerlein, E. (2000) Biomineralization: From Biology to Biotechnology and Medical Application, Wiley-VCH, Weinheim, Germany.

Ball, P. (1999) The Self-Made Tapestry: Pattern Formation in Nature, Oxford University Press, Oxford, UK.

Banfield, J.F., Moreau, J.W., Chan, C.S., Welch, S.A., and Little, B. (2001) Mineralogical biosignatures and the search for life on Mars. Astrobiology 1:447-465.

Beloin, C., Roux, A., and Ghigo, J.M. (2008) Escherichia coli biofilms. Curr Top Microbiol Immunol 322:249-289.

Berg, J.M., Tymoczko, J.L., and Stryer, L. (2007) Biochemistry, $6^{\text {th }}$ ed., W.H. Freeman and Company, New York.

Cady, S.L., Farmer, J.D., Grotzinger, J.P., Schopf, J.W., and Steele, A. (2003) Morphological biosignatures and the search for life on Mars. Astrobiology 3:351-368.

Early, J.W., Osthaus, B.B., and Milne I.H. (1953) Purification and properties of montmorillonite. Am Mineral 38:707724.

Golden, D.C., Ming, D.W., Schwandt, C.S., Lauer, H.V., Jr., and Socki, R.A. (2001) A simple inorganic process for formation of carbonates, magnetite, and sulfides in martian meteorite ALH84001. Am Mineral 8:370-375.

Gómez Gómez, J.M., Medina, J., Hochberg, D., Mateo-Martí, E., Martínez-Frías, J., and Rull F. (2014) Drying bacterial biosaline patterns capable of vital reanimation upon rehydration: novel hibernating biomineralogical life formations. Astrobiology 14:589-602. 
Hanlin, J.H., Lombardi, S.J., and Slepecky, R.A. (1985) Heat and UV light resistance of vegetative cells and spores of Bacillus subtilis Rec-mutants. J Bacteriol 163:774-777.

López, D., Vlamakis, H., and Kolter, R. (2010) Biofilms. Cold Spring Harb Perspect Biol 2, doi:10.1101/cshperspect .a000398.

McCord, T.B., Hansen, G.B., Fanale, F.P., Carlson, R.W., Matson, D.L., Johnson, T.V., Smythe, W.D., Crowley, J.K., Martin, P.D., Ocampo, A., Hibbitts, C.A., and Granahan, J.C. (1998) Salts on Europa's surface detected by Galileo's Near Infrared Mapping Spectrometer. Science 280:1242-1245.

Osterloo, M.M., Hamilton, V.E., Bandfield, J.L., Glotch, T.D., Baldridge, A.M., Christensen, P.R., Tornabene, L.L., and Anderson, F.S. (2008) Chloride-bearing materials in the southern highlands of Mars. Science 319:1651-1654.

Postberg, F., Schmidt, J., Hillier, J., Kempf, S., and Srama, R. (2011) A saltwater reservoir as the source of a compositionally stratified plume on Enceladus. Nature 474:620-622.

Reith, F., Rogers, S.L., McPhail, D.C., and Webb, D. (2006) Biomineralization of gold: biofilms on bacterioform gold. Science 313:233-236.

Rothery, D.A., Gilmour, I., and Sephton, M.A. (2011) An Introduction to Astrobiology, $2^{\text {nd }}$ ed., Cambridge University Press, Cambridge, UK.

Silhavy, T.J., Kahne, D., and Walker, S. (2010) The bacterial cell envelope. Cold Spring Harb Perspect Biol 2, doi: 10.1101/cshperspect.a000414.

Sirdeshmukh, D.B., Sirdeshmukh, L., and Subhadra, K.G. (2001) Alkali Halides: A Handbook of Physical Properties, Springer-Verlag, Berlin.

Wright, M.R. (2007) An Introduction to Aqueous Electrolyte Solution, John Wiley \& Sons, Chichester, UK.
Address correspondence to:

José María Gómez Gómez

Laboratory of BioMineralogy

and Astrobiological Research (LBMARS)

Unidad Asociada UVA-CSIC

Edificio INDITI

Av. Francisco Valles 8

Parque Tecnologico de Boecillo

Parcela 203

E-47151

Boecillo, Valladolid

Spain

E-mail: jmgomezseg@gmail.com

Submitted 26 October 2015

Accepted 24 February 2016

$\begin{aligned} & \text { Abbreviations Used } \\ \mathrm{BSF} & =\text { biosaline formation } \\ \mathrm{DLA} & =\text { diffusion-limited aggregation } \\ \mathrm{EDX} & =\text { energy dispersive X-ray } \\ \mathrm{EPS} & =\text { extrapolymeric substances } \\ \mathrm{HM} & =\text { humic material } \\ \mathrm{MonNa} & =\text { montmorilloniteNa } \\ \mathrm{OM} & =\text { outer membrane } \\ \mathrm{SDP} & =\text { saline drying pattern } \\ \mathrm{SEM} & =\text { scanning electronic microscope }\end{aligned}$

